Pacific Journal of Mathematics

PTOLEMY'S INEQUALITY, CHORDAL METRIC
MULTIPLICATIVE METRIC S. KLAMRIN AND A. MET 


\title{
PTOLEMY'S INEQUALITY, CHORDAL METRIC, MULTIPLICATIVE METRIC
}

\author{
M. S. Klamkin and A. Meir
}

Ptolemy's inequality in $\boldsymbol{R}^{2}$ states: If $A, B, C, D$ are vertices of a quadrilateral, then

$$
A B \cdot C D+B C \cdot A D \geqq A C \cdot B D
$$

with equality only $A B C D$ is a convex cyclic quadrilateral. A real normed linear vector space is called ptolemaic if

$$
\|x-y\|\|z\|+\|y-z\|\|x\| \geqq\|z-x\|\|y\|
$$

for all $x, y$ and $z$ in the space and it is called symmetric if

$$
\|\lambda x-y\|=\|x-\lambda y\|
$$

for all unit vectors $x, y$ and real $\lambda$. The equivalence of these two properties of a normed linear space is established and related results concerning distance functions in such spaces are proven.

Although Ptolemy's inequality is a useful tool and has often been applied (e.g., see [7]) it does not seem to be as widely known as would be desirable. Recently Apostol [1] gave an elegant proof of this inequality using complex numbers in the plane (see also [2], [4] and [5]) and extended the inequality to $\boldsymbol{R}^{3}$ thereafter. Apostol used Ptolemy's inequality to show that the chordal distance

$$
\chi(a, b)=\frac{|a-b|}{\sqrt{1+|a|^{2}} \sqrt{1+|b|^{2}}},
$$

defined for pairs of complex numbers, satisfies the triangle inequality $\chi(a, b)+\chi(b, c) \geqq \chi(a, c)$. In an earlier paper, Schoenberg [9], answering a problem raised by Blumenthal, proved the following: If $S$ is a real, seminormed space which is ptolemaic then the seminorm is a norm which springs from an inner product. In this note we wish to treat these results from a different point of view. We provide simpler proofs for some of the earlier results and extend a recent result of Schattschneider [6], [8].

2. Definition 2. Let $X$ be real normed linear space with norm $\|\cdot\|$.

(i) $X$ is called ptolemaic if for every $x, y, z \in X$ we have

$$
\|x-y\| \cdot\|z\|+\|y-z\| \cdot\|x\| \geqq\|x-z\| \cdot\|y\| .
$$

(ii) $X$ is called symmetric if for every $x, y \in X$ with $\|x\|=$ 
$\|y\|=1$ and for all real $\lambda$ we have

$$
\|\lambda x-y\|=\|x-\lambda y\| .
$$

3. Theorem 1. Let $(X,\|\cdot\|)$ be normed linear space. Then $X$ is ptolemaic if and only if $X$ is symmetric.

Proof. Suppose $X$ is symmetric. Let $x, y, z \in X$; we wish to prove (2.1). Clearly we may assume without loss of generality that $\|x\|>0,\|y\|>0,\|z\|>0$. Now, by (2.2),

$$
\|x-y\|=\left\|\frac{x}{\|x\|}\right\| y\left\|-\frac{y}{\|y\|}\right\| x\|\|=\|x\| \cdot\|y\| \| \frac{x}{\|x\|^{2}}-\frac{y}{\|y\|^{2}}
$$

and similar relations hold for the pair of vectors $x$ and $z$ and for $y$ and $z$. Thus (2.1) is equivalent to the triangle inequality for the vectors $x /\|x\|^{2}, y /\|y\|^{2}$ and $z /\|z\|^{2}$ in $X$. Conversely, if $X$ is ptolemaic, then by [9], $X$ is a real inner product space. (2.2) is then immediate, i.e., $X$ is symmetric.

CoRollaries. (i) $\boldsymbol{R}_{n}(n=1,2, \cdots)$ is ptolemaic, for, it is clearly symmetric.

(ii) If $X$ is a symmetric normed linear space, then the distance function

$$
d(x, y)=\frac{\|x-y\|}{\|x\| \cdot\|y\|}
$$

defined for $\|x\|,\|y\|>0$, satisfies the triangle inequality. For, by (3.1), the triangle inequality for $d(x, y)$ follows from the triangle inequality in $X$.

We note that the proof of Ptolemy's inequality using the symmetry condition is, in $\boldsymbol{R}^{n}$, equivalent to using inversion.

4. The chordal metric. We shall establish the following extension of Apostol's result mentioned in our introduction.

THeOREM 2. Let $(X,\|\|$.$) be a normed linear space. If X$ is symmetric, then the chordal distance given by

$$
\chi(x, y)=\frac{\|x-y\|}{\left(\alpha+\beta\|x\|^{p}\right)^{1 / p} \cdot\left(\alpha+\beta\|y\|^{p}\right)^{1 / p}}
$$

is a metric for every $\alpha>0, \beta \geqq 0, p \geqq 1$.

Proof. We only have to prove that $\chi$ satisfies the triangle inequality. Let $x, y, z$ be arbitrary vectors in $X$. Then by the triangle inequality 


$$
\alpha \cdot(\|x-y\|+\|y-z\|)^{p} \geqq \alpha \cdot\|x-z\|^{p},
$$

and since $X$ is ptolemaic,

$$
\beta \cdot(\|z\| \cdot\|x-y\|+\|x\| \cdot\|y-z\|)^{p} \geqq \beta \cdot(\|y\| \cdot\|x-z\|)^{p} .
$$

Adding (4.2) and (4.3) and using Minkowski's inequality, we get

$$
\begin{gathered}
\|x-y\| \cdot\left(\alpha+\beta\|z\|^{p}\right)^{1 / p}+\|y-z\|\left(\alpha+\beta\|x\|^{p}\right)^{1 / p} \\
\geqq\|x-z\|\left(\alpha+\beta\|y\|^{p}\right)^{1 / p}
\end{gathered}
$$

which proves that $\chi$ in (4.1) satisfies the triangle inequality.

5. A multiplicative metric. We shall establish the following extension of Schattschneider's result [8].

THeOREM 3. Let $(X,\|\cdot\|)$ be a normed linear vector space. If $X$ is symmetric, then the distance function defined by

$$
\begin{array}{rlrl}
d(x, y) & =\frac{\|x-y\|}{\left(\|x\|^{p}+\|y\|^{p}\right)^{1 / p}}, & \text { if } & \|x\|+\|y\|>0 \\
& =0 \quad, \text { if }\|x\|+\|y\|=0
\end{array}
$$

is a metric for every $p \geqq 1$.

Proof. Denote, for brevity, $\|x-y\|=a,\left(\|x\|^{p}+\|y\|^{p}\right)^{1 / p}=a^{\prime}$, $\|y-z\|=b,\left(\|y\|^{p}+\|z\|^{p}\right)^{1 / p}=b^{\prime}$ and $\|z-x\|=c,\left(\|z\|^{p}+\|x\|^{p}\right)^{1 / p}=$ $c^{\prime}$. We only need to prove the triangle inequality for $d(x, y)$, i.e., with the above notation, that

$$
\frac{a}{a^{\prime}}+\frac{b}{b^{\prime}} \geqq \frac{c}{c^{\prime}} .
$$

By the triangle inequality of the norm,

$$
a+b \geqq c,
$$

and by Ptolemy's inequality,

$$
a\|z\|+b\|x\| \geqq c\|y\| .
$$

If $c^{\prime} \geqq a^{\prime}$ and $c^{\prime} \geqq b^{\prime}$, then (5.2) follows from (5.3). If $c^{\prime} \leqq a^{\prime}$ and $c^{\prime} \leqq b^{\prime}$, then, one sees easily, $\|y\| c^{\prime} \geqq\|z\| a^{\prime}$ and $\|y\| c^{\prime} \geqq\|x\| b^{\prime}$. Hence, (5.2) follows from (5.4). In the remaining case, $c^{\prime}$ is between $a^{\prime}$ and $b^{\prime}$, say $a^{\prime}<c^{\prime}<b^{\prime}$ or equivalently $\|x\|<\|y\|<\|z\|$. Now, using the inequality $u^{p}+v^{p} \geqq 2^{1-p}(u+v)^{p}$ and then (5.3) and (5.4), we obtain

$$
a b^{\prime}+b a^{\prime} \geqq 2^{(1-p) / p}(a\|y\|+a\|z\|+b\|x\|+b\|y\|) \geqq 2^{1 / p} \cdot c \cdot\|y\| .
$$


A simple calculation shows that, because of $\|x\|<\|y\|<\|z\|$, we have

$$
2^{1 / p} \cdot\|y\| \geqq \frac{a^{\prime} b^{\prime}}{c^{\prime}}
$$

Whence,

$$
a b^{\prime}+b a^{\prime} \geqq a^{\prime} b^{\prime} \frac{c}{c^{\prime}} .
$$

This proves (5.1) in the last case.

CoRollary. The multiplicative distance defined by (5.1) is a metric in $\boldsymbol{R}^{n}(n=1,2, \cdots)$ and, in fact, in any inner product space. (Schattschneider's metric corresponds to the special case $p=1$ in $\boldsymbol{R}^{n}$.)

We do not know whether or not $d(x, y)$ of (5.1) is a metric for every $p \geqq 1 / 2$. We can prove that the triangle inequality holds if $p=1 / 2$ and fails if $p=1 / 4$.

\section{REFERENCES}

1. T. M. Apostol, Ptolemy's inequality and the chordal metric, Math. Mag., 40 (1967), 233-235.

2. S. Barnard and J. M. Childs, Higher Algebra, MacMillan, London, 1949, 78.

3. G. H. Hardy, J. E. Littlewood, G. Pólya, Inequalities, Cambridge University Press, London, 1934, 261.

4. T. Hayashi, Two theorems on complex numbers, Tôhoku Math. J., 4 (1913/14), 68-70.

5. M. S. Klamkin, Triangle inequalities from the triangle inequality, El. der Math., $\mathbf{3 4}$ (1979), 49-55.

6. Letter to and reply by the Editors, Math. Mag., 50 (1977), 55-56; 51 (1978), 207-208.

7. D. Pedoe, A geometric proof of the eqivalence of Fermat's principle and Snell's law, Amer. Math. Monthly, 71 (1964), 543.

8. D. J. Schattschneider, A Multiplicative metric, Math. Mag., 49 (1976), 203-205.

9. I. J. Schoenberg, A remark on M. M. Day's characterization of inner-product spaces and a conjecture of L. M. Blumenthal, Proc. Amer. Soc., 3 (1952), 961-964.

Received May 2, 1980.

University of Alberta

Edmonton, Alberta T6G 2G1

CANADA 


\section{PACIFIC JOURNAL OF MATHEMATICS}

\section{EDITORS}

DONALD BABBITT (Managing Editor)

University of California

Los Angeles, CA 90024

Hugo Rossi

University of Utah

Salt Lake City, UT 84112

C. C. MOore and Arthur Agus

University of California

Berkeley, CA 94720
J. DugundJI

Department of Mathematics

University of Southern California

Los Angeles, CA 90007

R. FinN and J. MILGRAM

Stanford University

Stanford, CA 94305

\section{ASSOCIATE EDITORS}
R. ARENS
E. F, BECKENBACH
B. H. NeumanN
F. WOLF
K. YoSHIDA

\section{SUPPORTING INSTITUTIONS}

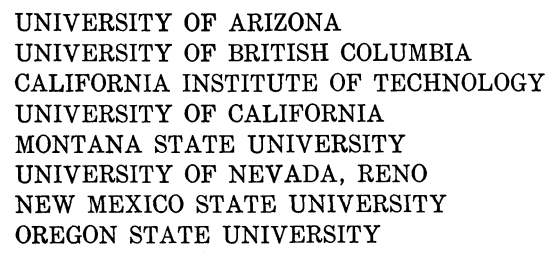

UNIVERSITY OF ARIZONA

UNIVERSITY OF BRITISH COLUMBIA

CALIFORNIA INSTITUTE OF TECHNOLOGY

UNIVERSITY OF CALIFORNIA

MONTANA STATE UNIVERSITY

UNIVERSITY OF NEVADA, RENO

NEW MEXICO STATE UNIVERSITY

OREGON STATE UNIVERSITY

\author{
UNIVERSITY OF OREGON \\ UNIVERSITY OF SOUTHERN CALIFORNIA \\ STANFORD UNIVERSITY \\ UNIVERSITY OF AAWAII \\ UNIVERSITY OF TOKYO \\ UNIVERSITY OF UTAH \\ WASHINGTON STATE UNIVERSITY \\ UNIVERSITY OF WASHINGTON
}

The Supporting Institutions listed above contribute to the cost of publication of this Journal, but they are not owners or publishers and have no responsibility for its content or policies,

Mathematical parers intended for publication in the Pacific Journal of Mathematics should be in typed form or offset-reproduced, (not dittoed), double spaced with large margins. Please do not use built up fractions in the text of the manuscript. However, you may use them in the displayed equations. Underline Greek letters in red, German in green, and script in blue. The first paragraph or two must be capable of being used separately as a synopsis of the entire paper. Please propose a heading for the odd unmbered pages of less than 35 characters. Manuscripts, in triplicate, may be sent to any one of the editors. Please classify according to the scheme of Math. Reviews, Index to Vol. 39. Supply name and address of author to whom proofs should be sent. All other communications should be addressed to the managing editor, or Elaine Barth, University of California, Los Angeles, California, 90024.

50 reprints to each author are provided free for each article, only if page charges have been substantially paid. Additional copies may be obtained at cost in multiples of 50 .

The Pacific Journal of Mathematics is issued monthly as of January 1966, Regular subscription rate: $\$ 114.00$ a year $(6$ Vol., 12 issues). Special rate: $\$ 57.00$ a year to individual members of supporting institution.

Subscriptions, orders for numbers issued in the last three calendar years, and changes of address shoud be sent to Pacific Journal of Mathematics, P.O. Box 969, Carmel Valley, CA 93924, U.S.A. Old back numbers obtainable from Kraus Periodicals Co., Route 100, Millwood, NY 10546.

PUBLISHED BY PACIFIC JOURNAL OF MATHEMATICS, A NON-PROFIT CORPORATION

Printed at Kokusai Bunken Insatsusha (International Academic Printing Co., Ltd.). 8-8, 3-chome, Takadanobaba, Shinjuku-ku, Tokyo 160, Japan.

Copyright (C) 1982 by Pacific Journal of Mathematics Manufactured and first issued in Japan 


\section{Pacific Journal of Mathematics}

\section{Vol. 101, No. 2 December, 1982}

Jean Bourgain, A Hausdorff-Young inequality for $B$-convex Banach

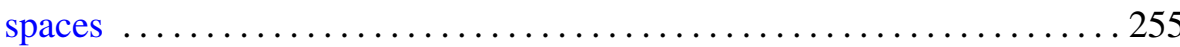

J. L. Brenner and Lorraine L. Foster, Exponential Diophantine

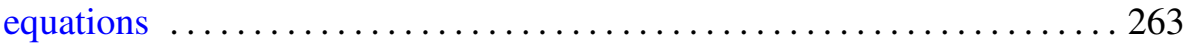

Henry H. Glover and William Duncan Homer, II, Fixed points on flag

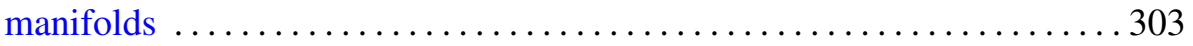

Lothar Hahn, A note on stochastic methods in connection with approximation theorems for positive linear operators $\ldots \ldots \ldots \ldots \ldots . \ldots 307$

James P. Henderson, Approximating cellular maps between low-dimensional polyhedra

V. K. Jain, Certain transformations of basic hypergeometric series and their

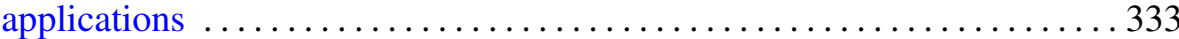

Charles David Keys, On the decomposition of reducible principal series

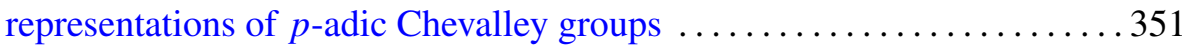

M. S. Klamkin and A. Meir, Ptolemy's inequality, chordal metric,

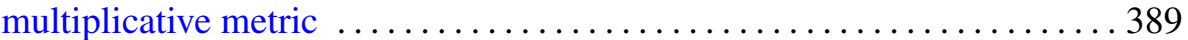

Robert F. Lax, Independence of normal Weierstrass points under

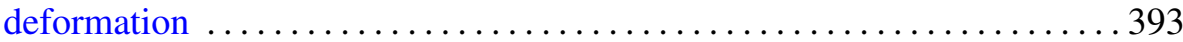

Leonid A. Luxemburg, On compactifications of metric spaces with

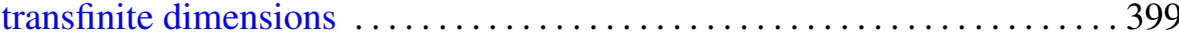

Carlton James Maxson, Martin Ross Pettet and Kirby C. Smith, On semisimple rings that are centralizer near-rings .....

Teodor C. Przymusiński, Extending functions from products with a metric factor and absolutes

Giorgio Talenti, A note on the Gauss curvature of harmonic and minimal surfaces

D. M. Terlinden, A spectral containment theorem analogous to the semigroup theory result $e^{t \sigma(A)} \subseteq \sigma\left(e^{t A}\right)$ 